\title{
GDO ANALİZLERİNDE KULLANILAN CRM İZOLATLARININ KONTROLLÜ MUHAFAZA KOŞULLARINDA TEKRAR KULLANIM OLANAKLARININ ARAŞTIRILMASI
}

\author{
Ayşe Dağdelen ${ }^{1 *}$, Nihal Akman ${ }^{1}$, Münevver Müge Çağal ${ }^{2}$ \\ ${ }^{1}$ Tarım ve Orman Bakanlığı, Gıda ve Yem Kontrol Merkez Araştırma Enstitüsü, Bursa, Türkiye \\ ${ }^{2}$ Bursa Teknik Üniversitesi, Mühendislik ve Doğa Bilimleri Fakültesi, Biyomühendislik Bölümü, Bursa, Türkiye \\ Geliş / Received: 20.12.2020; Kabul / Accepted: 09.03.2021; Online bask1 / Published online: 25.03.2021
}

Dağdelen, A., Akman, N., Çağal, M.M. (2021). GDO analizlerinde kullanılan CRM izolatlarının kontrollü muhafaza koşullarında tekrar kullanım olanaklarının araştırılması. GIDA (2021) 46(3) 515-527 doi: 10.15237 /gida. GD20142

Dağdelen, A., Akman, N., Çağal, M.M. (2021). Investigation of reuse capabilities of CRM isolates used in GMO analysis in the controlled storage conditions. GIDA (2021) 46(3) 515-527 doi: 10.15237/gida. GD20142

ÖZ

Genetiği değiştirilmiş organizmalar (GDO) potansiyel yararları nedeniyle tarımsal ürünler başta olmak üzere birçok alanda kullanılmaktadır. Yasal düzenlemelere göre gıda ve yemlerde GDO varlığının bilinmesi zorunluluktur. Analizlerde sonuçların doğtuluğu, kalibrasyon eğrisinin hazırlanması ve kalite kontrol çalışmalarında sertifikalı referans maddeler (CRM) kullanılmaktadır. Çalışma ile bitkisel ürünlerde GDO analizlerinde kullanılan CRM izolatlarının tekrar kullanılabilme olanaklarının belirlenmesi amaciyla dondurçözdür uygulaması ile meydana gelebilecek degradasyon araşturlmışır. Bunun için soya ve mısır CRM'lerinden elde edilen izolatlara kontrollü koşullarda belirli periyotlarla $(5,10,15,20 \mathrm{kez})$ dondurma ($\left.20 \pm 2^{\circ} \mathrm{C}\right)$ ve çözdürme $\left(22 \pm 2^{\circ} \mathrm{C}\right)$ işlemleri uygulanmıştr. Real time PCR cihazında yapılan analizler sonucunda 20 dondur-çözdür uygulamasına kadar CRM izolatlanının tekrar kullanılabildiği görülmüştür.

Anahtar kelimeler: Bitki, DNA, İzolat, Dondur-Çözdür

\section{INVESTIGATION OF REUSE CAPABILITIES OF CRM ISOLATES USED IN GMO ANALYSIS IN THE CONTROLLED STORAGE CONDITIONS}

\begin{abstract}
Genetically modified organisms (GMOs) are used in many areas, especially in agricultural crops, due to their potential benefits. According to legal regulations, it is imperative to know the presence of GMOs in food and feed. Certified reference materials (CRM) are used in the accuracy of the analyzes, preparation of calibration curve, and in quality control studies. In this study, degradation occuring with freeze-thaw application has been investigated in order to determine the reuse possibilities of CRM isolates used in GMO analysis in herbal products. For this, freezing $\left(-20 \pm 2{ }^{\circ} \mathrm{C}\right)$ and thawing $\left(22 \pm 2^{\circ} \mathrm{C}\right)$ processes were applied to the isolates obtained from soy and corn CRMs at certain periods $(5,10,15,20$ times) under controlled conditions. Real time PCR analysis results showed that up to 20 freeze-thaw applications, CRM isolates were reusable.
\end{abstract}

Keywords: Plant, DNA, Isolate, Freeze-Thaw

* Yazışmalardan sorumlu yazar / Corresponding author;

$\triangle$ ayse.dagdelen@tarimorman.gov.tr

(c) (+90) 2242464720

昷(+90) 2242461941

Ayşe Dağdelen; ORCID no: 0000-0002-9737-4652

Nihal Akman; ORCID no: 0000-0003-4611-9106

Münevver Müge Çağal; ORCID no: 0000-0002-1786-1216 


\section{GİRİ̧̧}

Biyoteknolojik çalışmaların en önemli ürünü olan genetiği değiştirilmiş organizmalar (GDO) (Genetically Modified Organisms - GMO), günümüzde tıp, tarım, veterinerlik başta olmak üzere geniş bir alanda kullanılmaktadır. Son 30 yılda DNA'nın yapısının daha iyi anlaşılması nedeniyle rekombinant DNA teknolojisine dayanan modern tarımsal biyoteknoloji alanı hızla gelişmiştir. Biyoteknolojik bu ürünlerin çiftçilere ve tüketicilere önemli tarımsal, çevresel, ekonomik, sağlık ve sosyal faydalar sağlaması ile de ticarileşmesi çok hızlanmıştur. Tarımsal ürünlerde yapılan bu çalışmalar sonucunda antibiyotik stres toleransı, böcek direnci, herbisit tolerans1, hastalık direnci, ürün kalitesi, tozlaşma kontrolü, büyüme ve verim özellikleri başta olmak üzere 44 farklı karakteristik özellik kazandırılmıştır. 1980'lerde başlayan bu çalışmalar 2020 yllına gelindiğinde ticari olarak 32 farklı bitkide 526 farklı GDO tipi üretilmiştir. Bu ürünlerin dünyada $\mathrm{ABD}$, Brezilya, Arjantin, Hindistan ve Kanada başta olmak üzere 26 ülkede 192 milyon hektar alanda ekimi yapilmaktadir. Ürünler içerisinde en çok soya (\%50), mısır (\%31), pamuk (\%13), kanola (\%5) ve diğerleri (\%1) olarak siralanmaktadır (Anonymous, 2020a).

GDO'ların potansiyel faydalarına rağmen hala bazı belirsizliklerinin bulunması, bilimsel olarak tartısılmasına ve tüketicilerde kaygılara neden olmaktadir. Bu durum gida ve yemlerdeki GDO varlı̆̆1 ile ilgili yasal düzenlemeler yapılmasına neden olmuştur. Avrupa Komisyonunun (European Commission - EC) 1829/2003 sayll düzenlemesinde gida ve yemlerde \%0.9'un üzerinde GDO bulunması durumunda etikette belirtilmelidir (Anonymous, 2003). Ülkemizde ise 5977 sayll "Biyogüvenlik Kanunu" ile "Genetik yapısı değiştirilmiş organizmalar ve ürünlerine dair yönetmelik" gereğince gıdalarda GDO kullanımı yasaklanmış olup yemlerdeki kullanımında ise EC ile benzer kisitlamalar bulunmaktadir (Anonymous, 2010a; 2010b).

Gıda veya yem ürünlerinde GDO varllğının belirlenmesinde proteine dayalı (Elisa yöntemi) ve nükleik aside dayalı (Polimeraz zincir reaksiyonu - PCR, DNA mikrodizi ve Sensörler) analitik yöntemler kullanılmaktadır. $\mathrm{Bu}$ yöntemler içerisinde hassasiyet ve hız avantajından dolayı PCR en yaygın kullanılan yöntemdir. Bu yöntem, iyi tanımlanmış DNA sekanslarının saptanmasına, çoğaltılmasina ve nispi olarak ölçülmesine dayanır. Spesifik bir DNA sekansının ölçülen miktarının başka bir DNA sekansının ölçülen miktaryyla ilişkilendirilmesi sonucunda bir DNA fragman oranı ortaya çıkar. Ölçülen bir floresan sinyalini çalışılan DNA fragmanının miktarı veya kütlesi için karakteristik bir miktara dönüştürmek için PCR'nin kalibre edilmesi gerekir (Corbisier vd., 2017). Bu amaçla farklı formlardaki sertifikalı referans maddeler (certified reference materials CRM) kullanilir. CRM'ler; laboratuvarlar tarafından elde edilen test sonuçlarına güveni artıran kalite güvence araçlanıdır. Kesin referans değerleri ve veriler sağlayarak laboratuvar cihazlarının kalibrasyonunda anahtar rol oynarlar (Anonymous, 2020b).

Analizlerde güvenilir ve ölçülebilir verileri elde etmek için kararlı standartların kullanılması gerekmektedir. Özellikle DNA bazlı CRM'lerin Kullanılacak DNA standartlan ölçülür, seri olarak seyreltilir ve daha sonra kalibrasyon çizgisi için kullanılır. $\mathrm{Bu}$ işlem prosedürünün özenli ve dikkatli yapılması gerektiğinden standartlanın muhafazası da önemlidir. Standartların uzun süreli muhafazası maliyet ve zamandan tasarruf sağlarken, DNA çözeltileri bozulmaya eğilimlidir (Röder vd., 2010).

DNA çift zincirli sarmal yapısı nedeniyle bilinen en kararlı moleküllerden biridir. Bu yapısal özelliğinden dolayı omurgalı bir hayvanın milyonlarca yıllık DNA'sı bile korunabilmektedir (Gaikwad, 2020). Ancak DNA çekirdek ya da organelden çıkarıldığında aynı durum sözkonusu değildir. DNA kararlı bir molekül olmasına rağmen, DNA'nın bütünlügü çevresel faktörlere ve özellikle de zamana bağlıdır (Rice ve Haussler, 2018). Uzun süre soğukta depolanan ya da kısa süre oda sıcaklığında bekletilen örneklerde zamanla meydana gelen UV radyasyonu, oksidasyon, hidroliz, fiziksel etkiler gibi enzimatik olmayan nükleik asit degradasyonu özellikle önemlidir. Lee (2010) tarafindan yapilan çalışmada muhafaza sırasında su ve oksijenin varlığının DNA'nın hidroliz ve oksidasyonuna 
neden olduğu bildirilmiştir. Rice ve Haussler (2018) tarafindan yapılan çalışmada ise, dondurulan izolatlarda oluşan buzların nükleik asitleri kesebileceği ya da dondurulunca daha küçük bir hacim içerisine sıkışmak zorunda kalan nükleik asit iplikçiklerinin fiziksel stres sonucu dolaşarak karmaşı bir yap1 oluşturabileceği belirtilmiştir.

Nükleik asitlerin muhafazasında kullanılan dondur-çözdür döngüsü uzun yıllardır kullanılan ancak dezavantajlarının tam olarak belirlenemediği bir yöntemdir. $\mathrm{Bu}$ döngünün kabul değerleri aslında nihai kullanım amacına ve ekstraksiyon tipine bağlıdır. Dondur-çözdür uygulamalanının olumsuz etkisini azaltmak için DNA'nın EDTA gibi gliserol/DMSO içeren bir solüsyon içerisinde, düşük iyon dayanıml, hafif alkalin tamponlu bir ortamda depolanmas önerilmiștir. Buna rağmen DNA degradasyonu oluşabilmektedir (Brunstein, 2015).

Nükleik asitlerin bozunma kinetiği üzerine uzun yıllardır araştırmalar yapılmaktadır. 1990'lardan günümüze kadar olan literatür incelendiğinde çalışmaların DNA ya da RNA'da yapıldığ görülmüştür. Bu çalışmalardan DNA'da yapılanlar sözkonusu olduğunda çoklu dondur-çözdür işlemlerinin DNA'nın stabilitesini etkilediği sonucuna Ross vd. (1990), Lahiri ve Schnabel (1993), Shao vd. (2012) ve Al-Warid (2014)'in çalışmalarında rastlanmıştır. Ancak DNA'nın etkilenmediği uygulamalar da mevcuttur (Widell vd., 1991; Bellete vd., 2003; Şanlıdağ vd., 2005; Schaudien vd., 2007; Rosmanith vd., 2010; Fan vd., 2019). Stabilite çalışmaları parazit ya da virüs gibi farklı kaynaklardan izole edilen nükleik asitlerde yapilmakla beraber dondur-çözdür uygulamalarındaki sıcaklık, süre, sıklı gibi parametrelerde de farklıliklar bulunmaktadır. Analiz yöntemi olarak elektroforez (Ross vd., 1990; Shao vd., 2012; Al-Warid, 2014), nested PCR (Halfon vd., 1996) ve Real Time kantitatif PCR (Granados vd., 2017; Schaudien vd., 2007) kullanılmışır. Ayrıca muhafazada ilave kimyasal kullanımı da degradasyonu azaltıcı yönde etki yapabilmektedir (Schaudien vd., 2007). Bitkisel kaynaklı numunelerde ise DNA'nin dondurçözdür uygulamalarına dayanımı ile ilgili literatürde herhangi bir çalışmaya rastlanmamıştır. $\mathrm{Bu}$ çalışma, GDO analizlerinde sonuçların doğruluğu, kalibrasyon eğrisinin hazırlanması ve kalite kontrol çalısmalarında sıklıkla kullanılan CRM'lerden elde edilen izolatların analiz prosedürü gereği dondur-çözdür uygulamalarına karşı dayanımlarının belirlenmesi amacıyla yapilmıştur.

\section{MATERYAL VE YÖNTEM}

\section{Materyal}

Çalışmada GDO analizlerinde en sık karşılaşılan bitki spesifik türlerden soyaya ait DP-305423-1 tipinin ERM-BF426c (\%1) ve ERM-BF426d (\%10); misira ait DAS-40278-9 tipinin ERMBF433c (\%1) ve ERM-BF433d (\%10) kodlu CRM'leri kullanılmıştur. Bu CRM'ler Avrupa Referans Materyalleri (European Reference Materials - ERM)'nden temin edilmiştir. CRM'ler analize alınıncaya kadar karanlıkta ve $4^{\circ} \mathrm{C}$ 'de muhafaza edilmiştir.

\section{Yöntem \\ CRM'lerin izolasyonu}

Çalışmada kullanılan izolasyon kiti Eurofins GENESpin'den temin edilmiştir (Anonymous, 2016). Bu kitler analize alınıncaya kadar oda sıcaklığında muhafaza edilmiştir. Kit içeriği Lysis Buffer (deterjan), Proteinaz K, Binding Buffer (DNA'yı kolona bağlama çözeltisi), CQW, W1 ve W2 kodlu yıkama çözeltileri ve Elution Buffer (DNA'yı kolondan ayıran çözelti)'dan oluşmaktadır. RNA inhibisyonu için SigmaAldrich marka R6513 RNase enzim çözeltisi kullanılmıştır. RNase çözeltisi çalışma süresi boyunca $-20^{\circ} \mathrm{C}$ de muhafaza edilmiştir. Tüm CRM'ler 0.2 g 2 mL'lik santrifüj tüplerine tartılmıs, $550 \mu \mathrm{L}$ Lysis Buffer ve $10 \mu \mathrm{L}$ Proteinaz $\mathrm{K}$ eklenerek Ika marka Ms1 model vortekste vortekslenmiş, $65^{\circ} \mathrm{C}$ 'de $30 \mathrm{dk}$. Biosan marka Ts100 tip çalkalamalı kuru blok 1 sııtıcıda tutulmuştur. Daha sonra $20 \mu \mathrm{L}$ Rnase enzimi eklenerek oda sicaklığında $30 \mathrm{dk}$. tutulmuştur. $14000 \mathrm{rcf}$ de 10 dk. santrifüj yapılmıştır. Santrifüj olarak Hettich marka Mikro 22r model santrifüj kullanılmıştır. DNA bağlanması aşaması için temiz ve berrak kısım 2 mL'lik tüpe alınmışır. Alınan kısım kadar Binding Buffer ve etanol ilave edilmiş ve $30 \mathrm{sn}$ vortekslenmiştir. Karışım filtreli tüpe aktarılarak 
11000 rpm'de 1 dk. santrifüj yapılmıştır. Yıkama ve kurutma aşamaları için alta geçen kısım dökülerek filtreye $400 \mu \mathrm{L}$ CQW eklenmiş ve 11000 rpm'de $1 \mathrm{dk}$. santrifüj yapılmıştır. Alta geçen kısım dökülerek filtreye $700 \mu \mathrm{L}$ W1 eklenmiştir. 11000 rpm'de 1 dk. santrifüj yapılmış, alta geçen k1sım dökülerek filtreye $200 \mu \mathrm{L}$ W2 eklenmiştir. 11000 rpm'de 2 dk. santrifüj yapılmış, filtreye yeniden $200 \mu \mathrm{L}$ CQW eklenmiştir. 11000 rpm'de $2 \mathrm{dk}$. santrifüj yapılmış, elüsyon aşamasında filtre $1.5 \mathrm{~mL}$ 'lik tüpe yerleştirilmiştir. Filtreye $100 \mu \mathrm{L} 70{ }^{\circ} \mathrm{C}$ sıcaklığında Elution Buffer ilave edilmiştir. Oda sicaklı̆̆ında $5 \mathrm{dk}$. inkübasyona bırakıldıktan sonra 11000 rpm'de 1 dk. santrifüj yapılarak filtre atılmıştır. Saflaştırma için numuneler kolonlara pipetlenerek 800 rcf'de 2 dk. santrifüj yapılmış ve kolonlar atılmıştır. İzolasyon sonucu elde edilen $100 \mu \mathrm{L}$ izolattan 1.5 $\mu \mathrm{L}$ pipetle alınmıştr. Nükleik asit saflıkları ve $\mathrm{ng} / \mu \mathrm{L}$ düzeyinde konsantrasyonlar Thermo Scientific marka Nanodrop 2000 model spektrofotometrede 260/280 $\mathrm{nm}$ dalga boyunda okunmuştur.

\section{Dondur-çözdür uygulamaları}

Miktar analizi ile ilgili referans alınan EURL metodlarında başlangıç konsantrasyonu olarak soya için $20 \mathrm{ng} / \mu \mathrm{L}$ ve misır için $40 \mathrm{ng} / \mu \mathrm{L}$ konsantrasyon düzeyi olması gerektiği belirtilmektedir. Bu nedenle soya ve misir CRM izolatlarının konsantrasyon düzeyleri dondurçözdür uygulamaları sirasinda meydana gelebilecek kayıplar dikkate alınarak başlangıçta 60 ng/ $\mu$ l olarak ayarlanmıştır. Her biri $100 \mu$ L olacak şekilde 1.5 mL'lik mikrosantrifüj tüplerine dağıtlan bu izolatlar $-20 \pm 2^{\circ} \mathrm{C}$ ve $22 \pm 2^{\circ} \mathrm{C}$ sicaklık koşullarında 5, 10, 15 ve 20 kez dondur-çözdür uygulamalarına maruz bırakılmıştır. Dondurçözdür uygulamaları 1 gün süreyle dondurma, 1 saat süresince çözdürme şeklinde kontrollü sıcaklık koşulları sağlanarak gerçekleştirilmiştir. Her 5 dondur-çözdür uygulamasında dondurçözdür işlemleri bitenler tekrar çözdürülmeksizin diğerlerinden ayrılarak son dondur-çözdür uygulamasına kadar muhafaza edilmiştir. Dondurçözdür işlemleri sonunda izolatların tamamı dolaptan çıkarllip çözdürülerek taze izole edilen CRM'lerle beraber Real time PCR'da \%GDO miktar analizi yapılmıştır.

\section{Miktar analizi}

Çalışmada soya için Mazzara vd. (2013) ve mısır için Savini vd. (2012) EURL metotları kullanılarak Real time PCR cihazında GDO miktar analizleri yapılmıştır (Anonymous, 2009; Savini vd., 2012; Mazzara vd., 2013). Miktar analizi için \%10 GDO'lu taze izolatlardan, dört seviyede (S1, S2, S3 ve S4) metotlarda belirtilen kopya sayılarında saf su ile standartlar hazırlanmıştur. Soya için bu seviyeler reaksiyon başına S1: $100 \mathrm{ng}, \mathrm{S} 2: 20 \mathrm{ng}$, S3: 4 ng ve S4: 0,8 ng \%10'luk DP305423 CRM içerecek şekilde kopya sayısı seyreltilerek elde edilmiştir. Misır için ise bu seviyeler reaksiyon başına S1: $200 \mathrm{ng}$, S2: $40 \mathrm{ng}$, S3: 8 ng ve S4: 1,33 ng \%10'luk DAS40278 CRM içerecek şekilde düzenlenmiştir. Amplifikasyonda ise öncelikle reaksiyon karışım çözeltisi hazırlanmış, bunun için reaktif çözeltisi, su, Ella Biotech'ten temin edilen referans ve hedef kısımlara özgü problar, reverse ve forward primerler metotlarda belirtilen miktarlarda $2 \mathrm{~mL}$ lik mikrosantrifüj tüplerinde birleştirilmiştir. Ardından düşük hızda vortekslenip kısa süre santrifüj edilmiştir. Reaksiyon karışım çözeltilerinde reaktif çözelti olarak TaqMan kullanılmıştır. Bu karışımdan ayrı bir mikrosantrifüj tüpüne $60 \mu \mathrm{L}$ alınarak üzerine $15 \mu \mathrm{L}$ numune/standart eklenip 10 saniye vortekslenip sonra kısa süre santrifüj edilmiştir. Daha sonra bu $75 \mu$ L'lik karışımdan plate kuyucuklarına (her kuyucuk 1 reksiyonu temsil etmektedir) otomatik pipetlerle her kuyucuğa 25 $\mu \mathrm{L}$ olacak şekilde pipetlenmiştir $(75 \mu \mathrm{L} / 3=25$ $\mu \mathrm{L})$. Optik filmler ile kapatilan kuyucuklar plate santrifüjde 3000 rpm'de $1 \mathrm{dk}$. santrifüj edilmiş, son olarak Real Time PCR cihazina yerleştirilmiştir. Başlangıç denatürasyonu $\left(95^{\circ} \mathrm{C}\right.$ sıcaklıkta 600 sn.), primer bağlanması $\left(95^{\circ} \mathrm{C}\right.$ sicaklikta 15 sn.) ve primer uzamasin $1\left(60^{\circ} \mathrm{C}\right.$ sıcaklıkta 60 sn.) içeren amplifikasyon 45 döngü olarak, Kopya Sayısı Metodu (Standart Eğri Metodu)'na göre gerçekleştirilerek hedef ve referans kısımlar için kalibrasyon eğrileri elde edilmiştir. GDO Analizlerinde Verifikasyon Rehberinde (Anonymous, 2018) yer alan doğrusallık, doğruluk ve kesinlik parametrelerine göre standart eğrilerin uygunluğu değerlendirildikten sonra elde edilen kopya sayılarından \% GDO miktarları aşağıdaki formülle hesaplanmıştur. 
$\%$ GDO $=$ (Hedef Kopya Sayıs1 / Referans Kopya Sayıs1) * 100

\section{İstatiksel yöntem}

Verilerin normal dağılıma göre uygunluğu Shapiro Wilks testi ile incelenmiştir. Verilerin normal dağ 1 lım göstermesi durumunda tek yönlü varyans analizi (ANOVA) yapılmıştır. Parametrik testlerin kullanılması durumunda betimleyici istatistikler ortalama \pm standart sapma olarak verilmiştir. İstatistiksel anlamll1k düzeyi olarak $\alpha=0,01 \mathrm{kabul}$ edilmiştir. Verilerin analizi SPSS v22 paket programı ile yapılmıştır.

\section{SONUÇ ve TARTIŞMA}

İzolasyon bulgular1

Nanodrop Spektrofotometresinde 260 ve $280 \mathrm{~nm}$ dalga boylarında CRM'lerden elde edilen izolatlarda yapılan absorbans ölçümleri sonucunda elde edilen başlangıç verileri Çizelge 1 ve Çizelge 2'de verilmiştir. Eurofins GENESpin kit protokolüne göre 260/280 nm'deki absorbansların oranı 1.6-1.9 arasında olmalıdır (Anonymous, 2016). Buna göre ölçüm sonuçlarının soya ve mısırın her iki konsantrasyon düzeyi için de uygun olduğu görülmüştür. Bu durum izolasyonun istenilen verim ve kalitede gerçekleştirildiğini göstermektedir.

Çizelge 1. Soya CRM izolatlarına ait Nanodrop Spektrofotometre ölçüm bulguları Table 1. Nanodrop Spectrophotometer measurement findings of Soybean CRM isolates

\begin{tabular}{ccccc}
\hline \multicolumn{5}{c}{ Soya CRM (DP-305423-1) } \\
\hline \multicolumn{5}{c}{$\% 10$ 'luk için } \\
No & $\begin{array}{c}\text { Nükleik asit } \\
\text { konsantrasyonu }(\mathrm{ng} / \mu \mathrm{L})\end{array}$ & $\begin{array}{c}\text { Saflık } \\
(260 / 280 \mathrm{~nm})\end{array}$ & $\begin{array}{c}\text { Nükleik asit } \\
\text { konsantrasyonu }(\mathrm{ng} / \mu \mathrm{L})\end{array}$ & $\begin{array}{c}\text { Saflık } \\
(260 / 280 \mathrm{~nm})\end{array}$ \\
\hline 1 & 137.6 & 1.88 & 116.0 & 1.78 \\
2 & 71.2 & 1.88 & 92.7 & 1.74 \\
3 & 87.4 & 1.85 & 66.1 & 1.77 \\
4 & 96.2 & 1.83 & 60.6 & 1.66 \\
5 & 101.3 & 1.80 & 101.8 & 1.71 \\
6 & 140.2 & 1.84 & 119.2 & 1.78 \\
7 & 71.4 & 1.86 & 74.8 & 1.70 \\
8 & 176.5 & 1.82 & 96.5 & 1.78 \\
\hline
\end{tabular}

Çizelge 2. Mısır CRM izolatlarına ait Nanodrop Spektrofotometre ölçüm bulguları Table 2. Nanodrop Spectrophotometer measurement findings of maize CRM isolates

\begin{tabular}{ccccc}
\hline \multicolumn{5}{c}{ Misır CRM (DAS-40278-9) } \\
\hline \multicolumn{5}{c}{$\% 10$ 'luk için } \\
No & $\begin{array}{c}\text { Nükleik asit } \\
\text { konsantrasyonu }(\mathrm{ng} / \mu \mathrm{L})\end{array}$ & $\begin{array}{c}\text { Saflı } \\
(260 / 280 \mathrm{~nm})\end{array}$ & $\begin{array}{c}\text { Nükleik asit lik için } \\
\text { konsantrasyonu }(\mathrm{ng} / \mu \mathrm{L})\end{array}$ & $\begin{array}{c}\text { Saflık } \\
(260 / 280 \mathrm{~nm})\end{array}$ \\
\hline 1 & 215.3 & 1.86 & 217.7 & 1.88 \\
2 & 92.2 & 1.78 & 157.0 & 1.85 \\
3 & 108.7 & 1.78 & 154.3 & 1.88 \\
4 & 97.1 & 1.71 & 154.2 & 1.87 \\
5 & 94.4 & 1.77 & 207.0 & 1.86 \\
6 & 100.6 & 1.76 & 140.3 & 1.85 \\
7 & 60.1 & 1.66 & 112.9 & 1.84 \\
8 & 102.3 & 1.64 & 120.7 & 1.86 \\
\hline
\end{tabular}


DNA'nin muhafazasinda major tehditlerden birisinin nükleaz kontaminasyonu olduğu bilinmektedir (Rice ve Haussler, 2018). DNA molekülü nükleazlara karşı duyarlı olduğundan bu bulaşanlardan kolayca etkilenebilmektedir. Bununla beraber iyi saflıktaki DNA'nın muhafaza sırasındaki dondur-çözdür döngülerinden etkilenmediği bildirilmiştir (Gaikwad, 2020). Çalışmamızdaki izolasyon bulguları dikkate alındığında sonuçlar bu görüşü desteklemektedir.

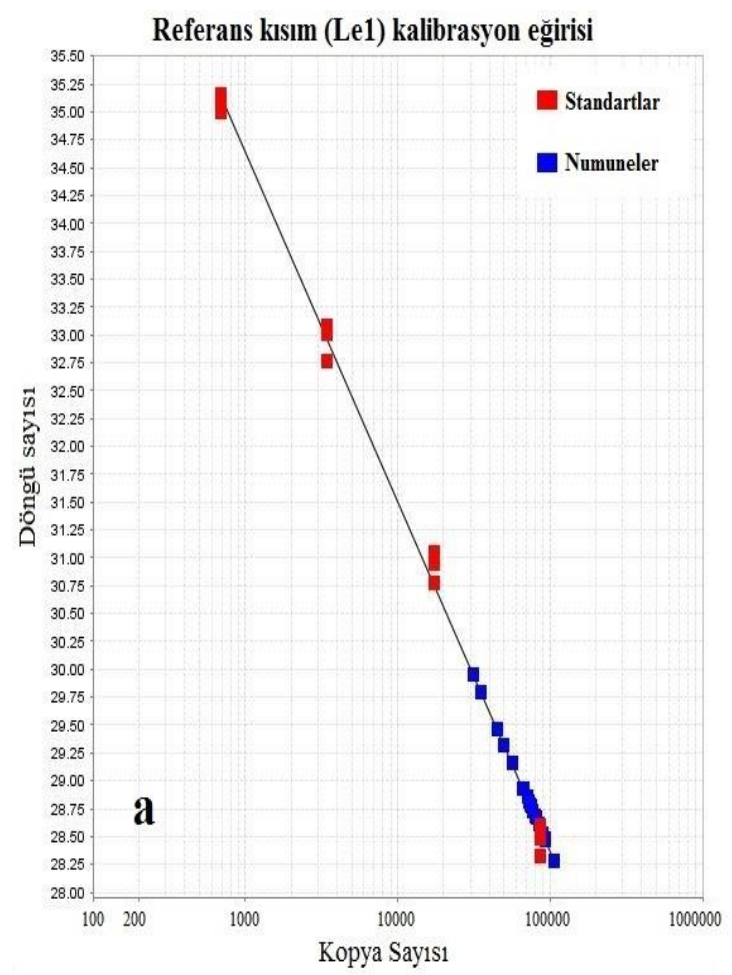

Soya CRM'ine ait \%GDO miktar bulguları Soya CRM'lerine ait \% GDO miktar analizleri sonucunda hesaplanan kalibrasyon eğrileri Şekil 1 ve Şekil 2'de verilmiştir. Bu kalibrasyon verilerinin kantitatif metodlar için metot verifikasyon parametreleri ve performans kriterleri (Anonymous, 2018)'ne uygunluğu Çizelge 3'de, Soya CRM izolatlarının dondur-çözdür uygulamaları sonrası Real Time PCR'da yapilan $\%$ GDO miktar bulguları da Çizelge 4, Şekil 3 ve Şekil 4'de verilmiştir.

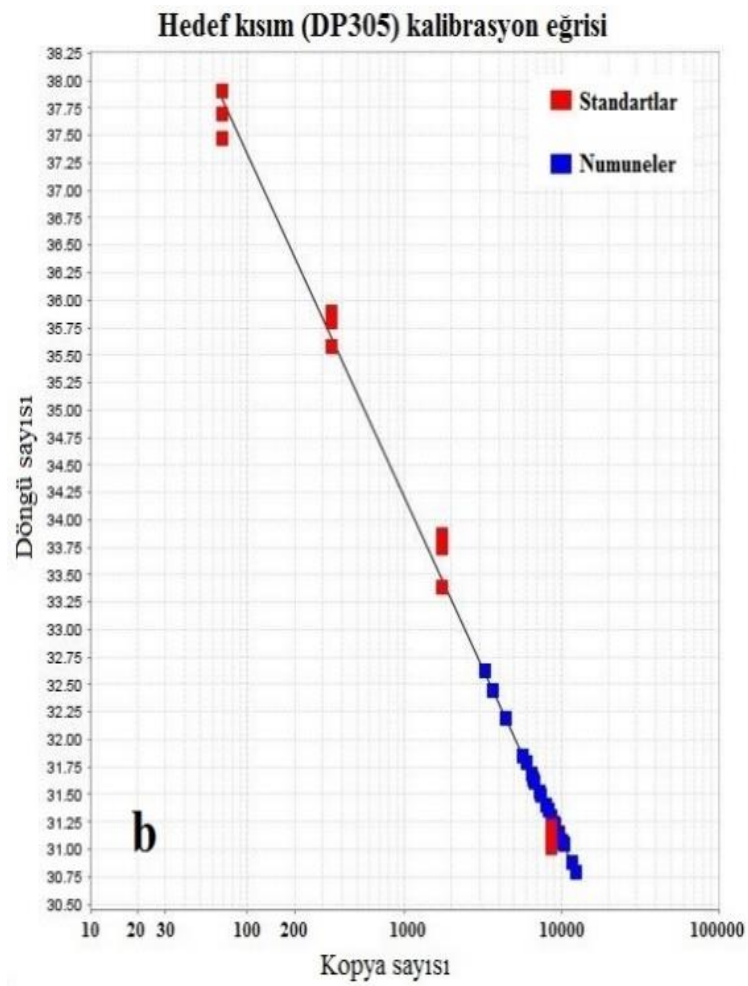

Şekil 1. \%10'luk Soya CRM'e ait kalibrasyon eğrileri, a: Referans kısım, b: Hedef kısım.

Figure 1. Calibration curves of 10\% soybean CRM, a: Reference part, $b$ : Target part.

Kalibrasyon bulgularn kabul edilebilir performans kriterleri (eğim ve korelasyon katsayısı) açısından değerlendirildiğinde, Çizelge 3'de görüldüğü gibi soya CRM numunelerinde her iki konsantrasyon düzeyi (\%1 ve \%10) için de uygun bulunmuştur. Bu kalibrasyona göre yapılan ölçümler sonucunda, Çizelge 4'de görüldüğü gibi \%10'luk soya CRM numunesinin 20 dondur-çözdür uygulaması sonucunda \%10.6'dan \%9.7 düzeyine düştüğü, \%1'lik CRM'de ise bu değişimin olmadığ1 saptanmıştır. Ancak her iki konsantrasyon için de değişimin istatistiksel olarak önemsiz olduğu görülmüştür $(\mathrm{P}>0.01)$.

\section{Misır CRM'ine ait \%GDO miktar bulguları}

Misir CRM'lerine ait \% GDO miktar analizleri sonucunda hesaplanan kalibrasyon eğrileri Şekil 5 ve Şekil 6'da verilmiştir. Bu kalibrasyon verilerinin kriterlere uygunluğu Çizelge 5'de ve Misır CRM izolatlarının dondur-çözdür uygulamaları sonrası Real Time PCR'da yapılan \% GDO miktar bulguları da Çizelge 6, Şekil 3 ve Şekil 4'de verilmiştir 

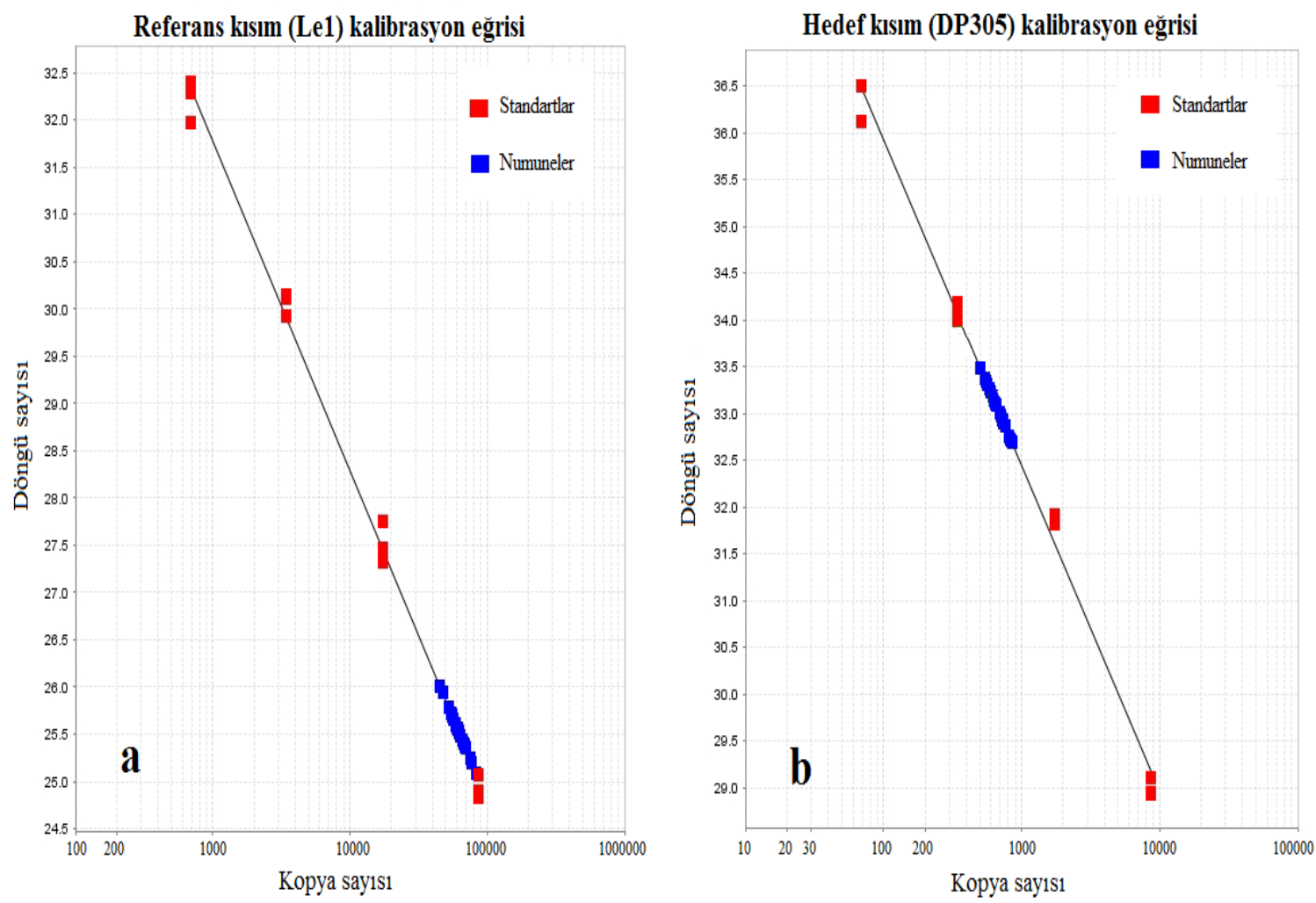

Şekil 2. \%1'lik Soya CRM'e ait kalibrasyon eğrileri, a: Referans kısım, b: Hedef kısım.

Figure 2. Calibration curves of 1\% soybean CRM, a: Reference part, b: Target part.

Çizelge 3. Real Time PCR'da soyaya ait kalibrasyon verileri ve kriterlere uygunluğu

Table 3. Calibration data of soybean in Real Time PCR and compliance with the criteria

\begin{tabular}{|c|c|c|c|c|c|}
\hline $\begin{array}{l}\text { \%GDO } \\
\text { miktar1 }\end{array}$ & $\begin{array}{l}\text { Doğrusallık } \\
\text { parametreleri }\end{array}$ & $\begin{array}{c}\text { Referans } \\
\text { k1sim }\end{array}$ & $\begin{array}{l}\text { Hedef } \\
\text { k1sim }\end{array}$ & Kriter & Değerlendirme \\
\hline \multirow{2}{*}{10} & $\mathrm{~m}$ & -3.13 & -3.12 & $-3.1 \geq m \geq-3.6$ & Uygun \\
\hline & $\mathrm{R}^{2}$ & 0.99 & 0.99 & $\mathrm{R}^{2} \geq 0.98$ & Uygun \\
\hline \multirow{2}{*}{1} & $\mathrm{~m}$ & -3.49 & -3.48 & $-3.1 \geq m \geq-3.6$ & Uygun \\
\hline & $\mathrm{R}^{2}$ & 0.99 & 0.99 & $\mathrm{R}^{2} \geq 0.98$ & Uygun \\
\hline
\end{tabular}

$\mathrm{m}$ : Kalibrasyon eğrisine ait eğim, $\mathrm{R}^{2}$ : Korelasyon katsayısı

$m$ : Slope of the calibration curve, $R^{2}$ : Correlation coefficient

Çizelge 4. Real Time PCR'da soyaya ait \%GDO miktar bulguları

Table 4. GMO\% content of soybean in Real Time PCR

\begin{tabular}{cccc}
\hline \multirow{2}{*}{ Dondur-çözdür sayıs1 } & \multirow{n}{*}{$\mathrm{n}$} & $\mathbf{\% 1 0}$ 'luk için & Soya \\
\cline { 3 - 4 } & 6 & $10.65 \pm 0.29$ & $1.03 \pm 0.04$ \\
Kontrol & 6 & $10.23 \pm 0.56$ & $1.05 \pm 0.06$ \\
5 & 6 & $10.34 \pm 0.38$ & $0.99 \pm 0.07$ \\
10 & 6 & $9.95 \pm 0.68$ & $1.01 \pm 0.06$ \\
15 & 6 & $9.72 \pm 0.48$ & $1.04 \pm 0.05$ \\
20 & Önemsiz & Önemsiz \\
\hline Önemlilik derecesi $(\mathrm{P}>0.01)$ & &
\end{tabular}

* Değerler ortalama \pm standart sapma $(\mathrm{n}=6)$ olarak verilmiștir. $(\mathrm{P}>0.01)$.

$V$ alues are given as mean $\pm S D(n=6)$. $(P>0.01)$. 


\section{Dondur Çözdür uygulamasının CRM'lere etkisi}

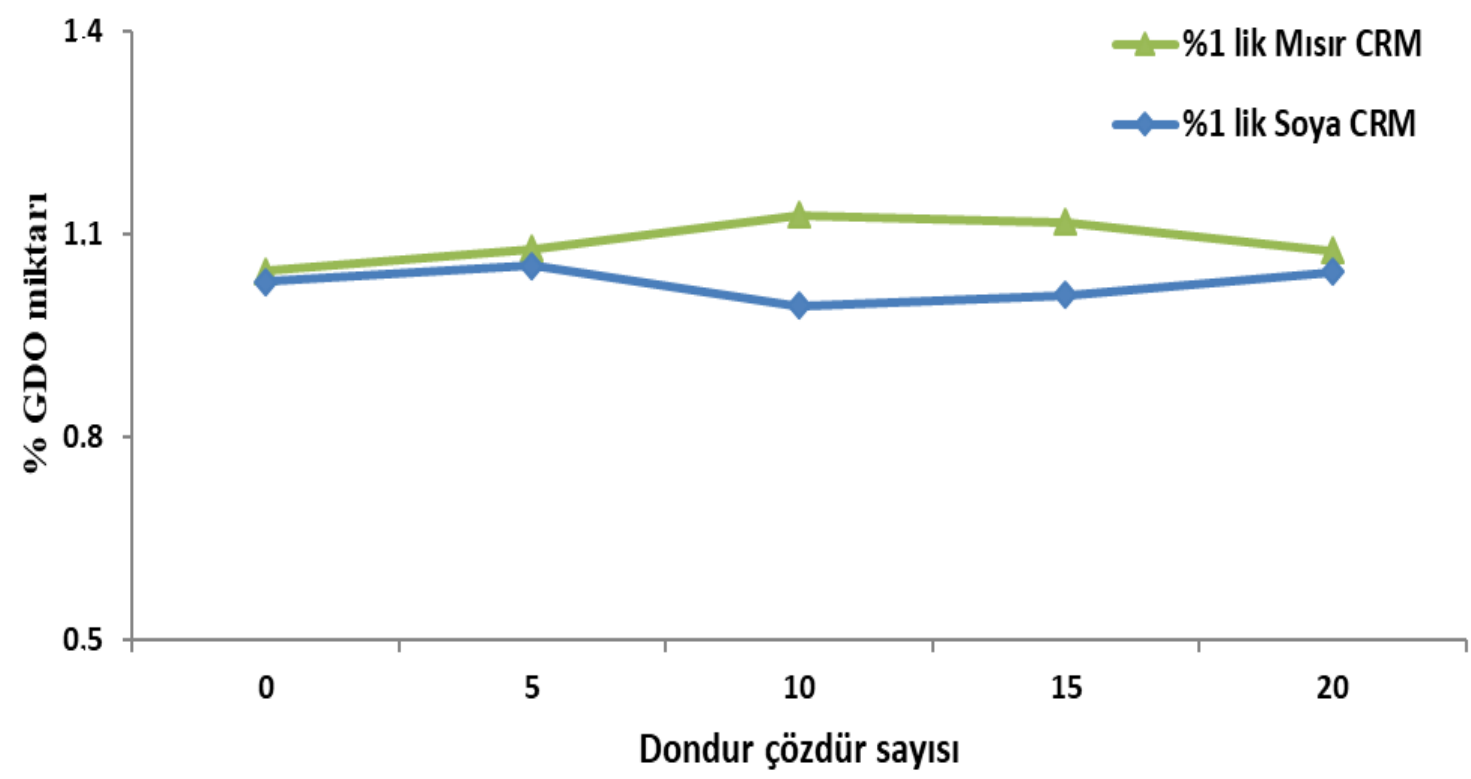

Şekil 3. \%1'lik soya ve mısır CRM'lere dondur-çözdür uygulamasının etkisi.

Figure 3. The effect of freeze-thaw application on $1 \%$ soybean and maize CRMs.

\section{Dondur Çözdür uygulamasının CRM'lere etkisi}

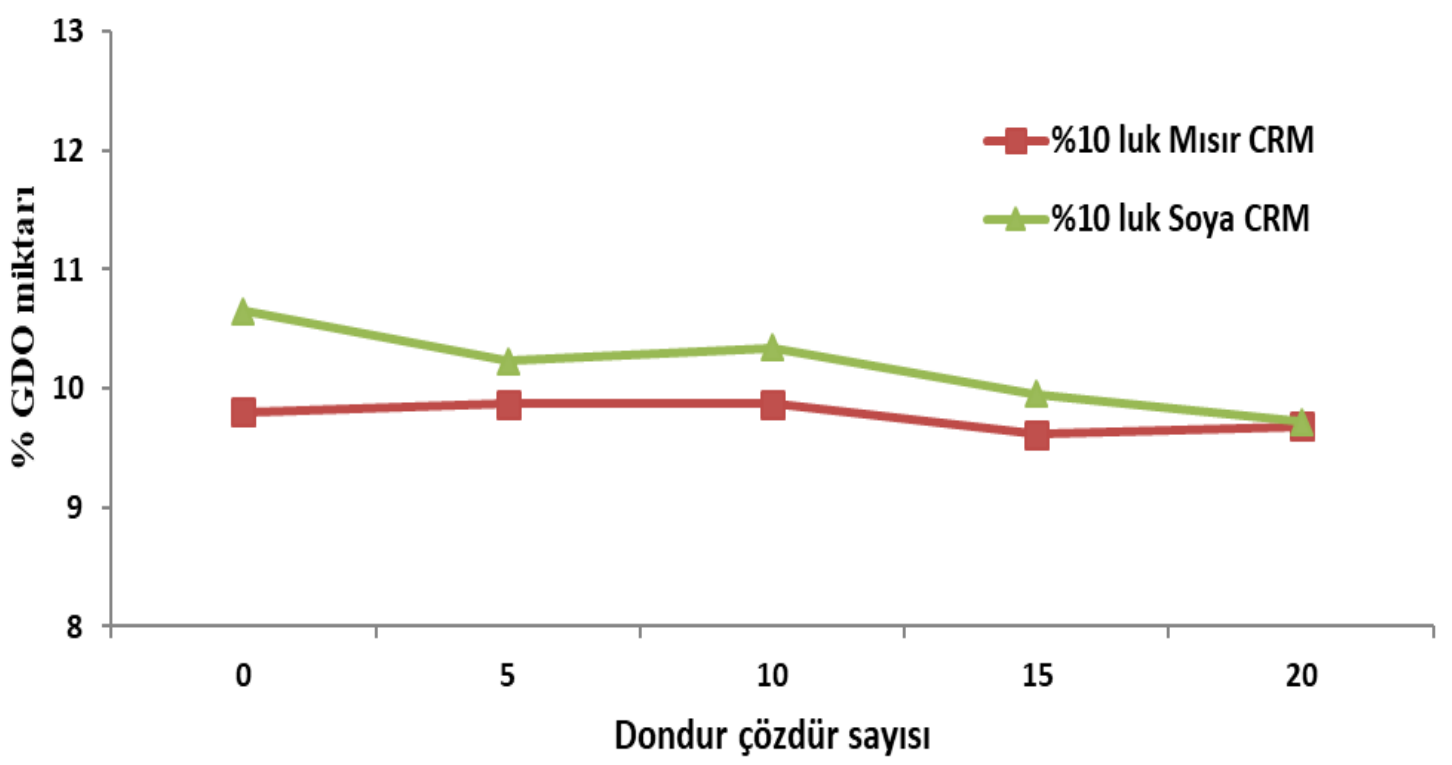

Şekil 4. \%10’luk soya ve mısır CRM'lere dondur-çözdür uygulamasının etkisi.

Figure 4. The effect of freeze-thaw application on $10 \%$ soybean and maize CRMs. 
Çizelge 5. Real Time PCR'da misıra ait kalibrasyon verileri ve kriterlere uygunluğu Table 5. Calibration data of maize in Real Time PCR and compliance with the criteria

\begin{tabular}{|c|c|c|c|c|c|}
\hline $\begin{array}{l}\text { \%GDO } \\
\text { miktar1 }\end{array}$ & $\begin{array}{l}\text { Doğrusallik } \\
\text { parametreleri }\end{array}$ & $\begin{array}{c}\text { Referans } \\
\text { k1sim }\end{array}$ & $\begin{array}{l}\text { Hedef } \\
\text { kısim }\end{array}$ & Kriter & Değerlendirme \\
\hline \multirow{2}{*}{10} & $\mathrm{~m}$ & -3.41 & -3.31 & $-3.1 \geq m \geq-3.6$ & Uygun \\
\hline & $\mathrm{R}^{2}$ & 0.99 & 0.99 & $\mathrm{R}^{2} \geq 0.98$ & Uygun \\
\hline \multirow{2}{*}{1} & $\mathrm{~m}$ & -3.43 & -3.47 & $-3.1 \geq m \geq-3.6$ & Uygun \\
\hline & $\mathrm{R}^{2}$ & 0.99 & 0.99 & $\mathrm{R}^{2} \geq 0.98$ & Uygun \\
\hline
\end{tabular}

$\mathrm{m}$ : Kalibrasyon eğrisine ait eğim, $\mathrm{R}^{2}$ : Korelasyon katsayısı $m$ : Slope of the calibration curve, $\mathrm{R}^{2}$ : Correlation coefficient

Çizelge 6. Real Time PCR'da misıra ait \%GDO miktar bulguları Table 6. GMO\% content of maize in Real Time PCR

\begin{tabular}{|c|c|c|c|}
\hline \multirow{2}{*}{ Dondur-çözdür sayis1 } & \multirow{2}{*}{$\mathrm{n}$} & \multicolumn{2}{|c|}{ Misir } \\
\hline & & \%10’luk için & $\% 1$ 'lik için \\
\hline Kontrol & 6 & $9.80 \pm 0.50$ & $1.05 \pm 0.03$ \\
\hline 5 & 6 & $9.87 \pm 0.54$ & $1.08 \pm 0.04$ \\
\hline 10 & 6 & $9.87 \pm 0.44$ & $1.13 \pm 0.04$ \\
\hline 15 & 6 & $9.62 \pm 0.29$ & $1.12 \pm 0.04$ \\
\hline 20 & 6 & $9.68 \pm 0.40$ & $1.08 \pm 0.06$ \\
\hline Önemlilik derecesi (P & & Önemsiz & Önemsiz \\
\hline
\end{tabular}

* Değerler ortalama \pm standart sapma $(\mathrm{n}=6)$ olarak verilmiştir. $(\mathrm{P}>0.01)$.

$V$ alues are given as mean $\pm S D(n=6) .(P>0.01)$.

Kalibrasyon bulgulan kabul edilebilir performans kriterleri (eğim ve korelasyon katsayısı) açısından değerlendirildiğinde, Çizelge 5'de görüldüğü gibi misir CRM numunelerinde her iki konsantrasyon düzeyi (\%1 ve \%10) için de uygun bulunmuştur. Bu kalibrasyona göre yapılan ölçümler sonucunda, Çizelge 6'da görüldüğü gibi misır CRM numunelerinde 20 dondur-çözdür uygulaması sonucunda her iki konsantrasyon için de değişimin istatistiksel olarak önemsiz olduğu görülmüştür $(\mathrm{P}>0.01)$.

Nükleik asitlerin, dondur-çözdür uygulamasına dayanımı ile ilgili literatürde yer alan çalışmalar incelendiğinde bir çok açıdan farklılıklar (numune kaynağı, matriksi, analiz yöntemi, uygulama parametreleri gibi) içerdiği görülmektedir. Ayrıca DNA ve RNA'nın muhafaza yöntemlerine karş1 dayanımlanının da farklı olabileceği göz önüne alındığında çalışmamızda elde edilen bulgular sadece DNA içeren çalş̧malar ile kıyaslanabilmiştir. Buna göre;

DNA'nın dondur-çözdür uygulamalarına karşı dayanımı ile ilgili yapılan çalışmalarda, degradasyonun olduğu ile olmadığını gösteren bulgulara rastlanılmıştır. DNA'nın dondur-çözdür uygulamalarından etkilenmediği benzer sonuçlara Widell vd., 1991; Bellete vd., 2003; Şanlıdă̆ vd., 2005; Schaudien vd., 2007 ve Fan vd., 2019'un çalışmalarında rastlanmıştur.

DNA, hücre içerisinde molekül olarak kararlı bir yapıya sahip iken izole edildiğinde DNA'nın dış etkenlere (sıcaklık, süre, 1şık, $\mathrm{pH}$, kesme kuvveti gibi) karşı dayanımı oldukça azalmaktadır (Gaikwad, 2020; Rice ve Haussler, 2018). Numune izolatlarında yapılmış çalışmalara bakıldığında ise; Schaudien vd. (2007) tarafından, Real Time PCR ile üç farklı DNA standardında ilave muhafaza kimyasalı (gliserol) kullanılarak dondur-çözdür uygulaması yapılmış, su içinde muhafaza edilen standartlarda 4 dondur-çözdür işleminden sonra DNA düzeyinde azalma olduğu, $\% 50$ gliserol içerisinde muhafaza edilenlerde ise 16 kez dondurup çözdürmenin bir etkisinin olmadığı bildirilmiştir. Gliserol kullanılarak DNA'nın dondur-çözdür uygulamasına dayanabildiği bu çalışmadan farklı olarak çalışmamız, gliserol olmadan da DNA izolatlarının dondur-çözdür uygulamalarına dayanabildiğini göstermiştir. 

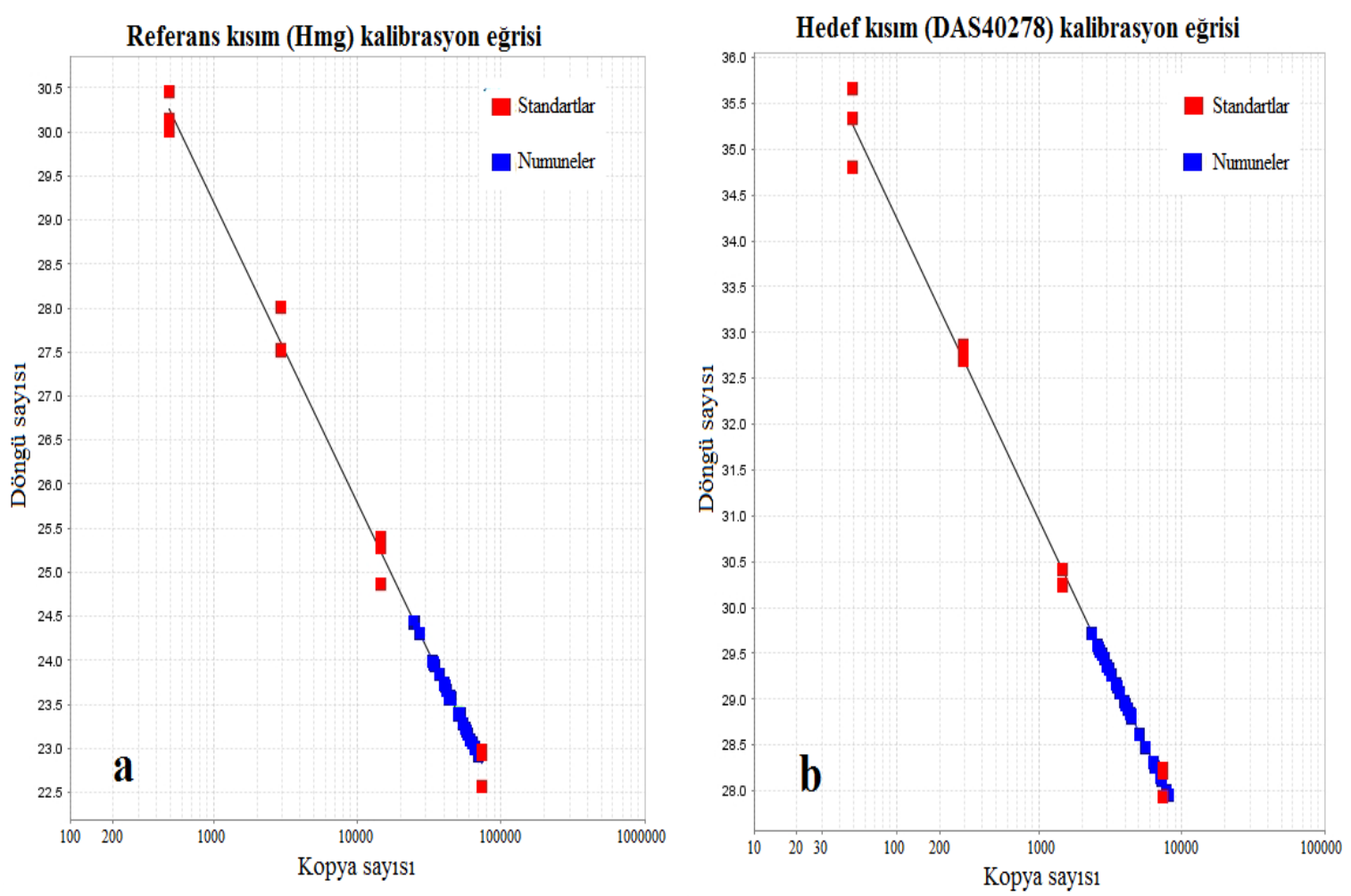

Şekil 5. \%10’luk Mısır CRM'e ait kalibrasyon eğrileri, a: Referans kısım, b: Hedef kısım.

Figure 5. Calibration curves of 10\% Maize CRM, a: Reference part, $b$ : Target part.
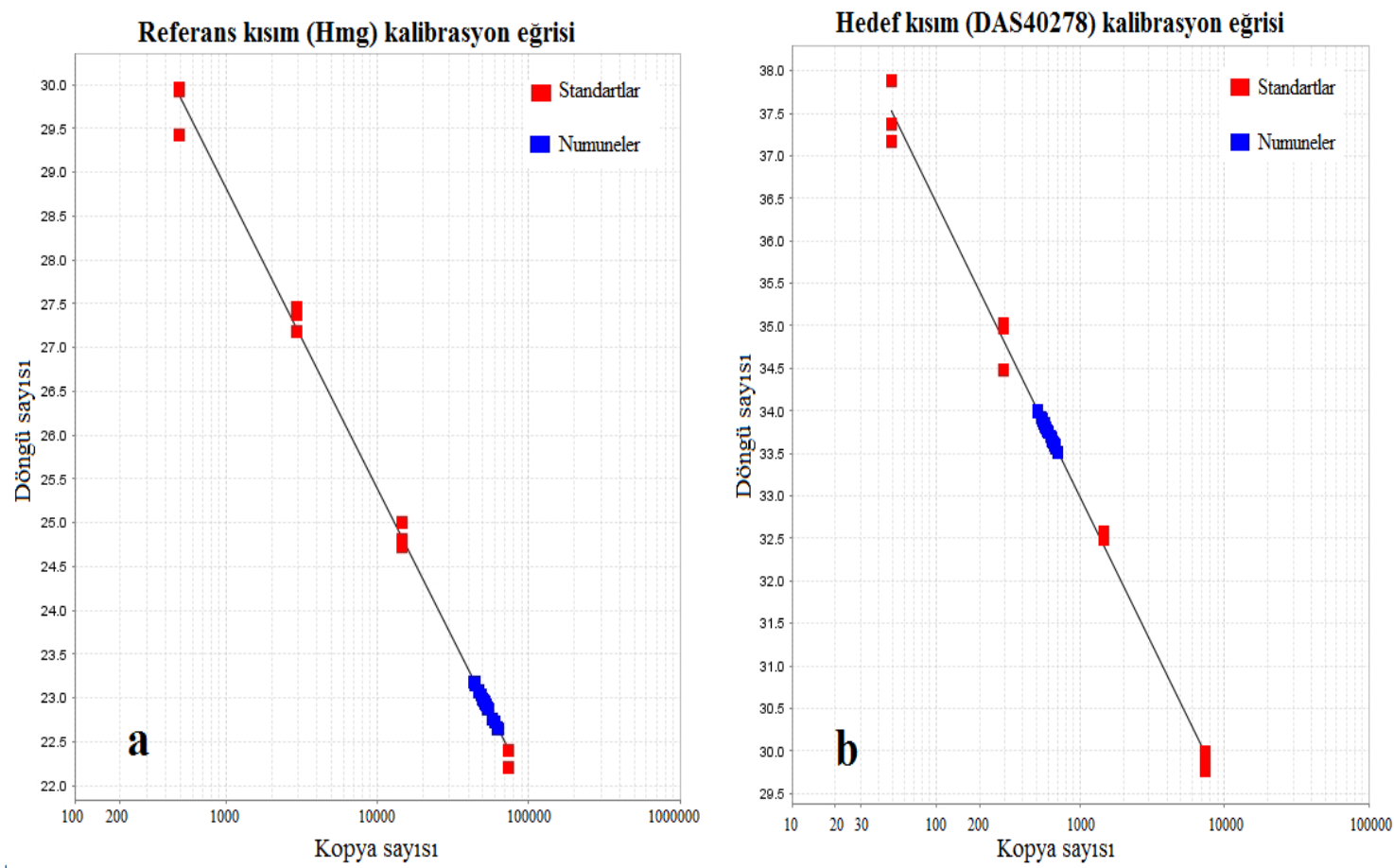

Şekil 6. \%1'lik Mısır CRM'e ait kalibrasyon eğrileri, a: Referans kısım, b: Hedef kısım.

Figure 6. Calibration curves of 1\% Maize CRM, $a$ : Reference part, $b$ : Target part. 
Farklı çalışma alanlarındaki araştırmacılar tarafından DNA'nın stabilitesi üzerine hangi mekanizmaların nasıl etki ettiği konusu Rossmanith vd. (2010) tarafindan yapilan çalışmada açıklanmıştır. Bakteri standardında (Listeria monocytogenes ve Salmonella Typhimurium'a ait) yapilmış bu çalışmada dondur-çözdür uygulamaları da ele alınmış ve 20 dondur-çözdür sonrasındaki $\Delta \mathrm{Ct}$ değerleri değerlendirilmiştir. Uzun genomik DNA'larda dondurup çözdürmenin etkisi varken, kısa zincirli oligonükleotitlerde ise herhangi bir değişimin olmadığ1 bildirilmiştir. Ct değerlerindeki artışa neden olan mekanizmanın dondur-çözdür sırasındaki buz kesmelerinden kaynaklandığı ileri sürülerek DNA düzeyindeki degradasyon $\mathrm{Ct}$ değerleri ile ilişkilendirilmiştir. Kendi çalışmamızda ise standart eğri metodu ile kantitatif bir analiz yapılmış bulgular $\mathrm{Ct}$ değerlerinin değişimi olarak değil \%GDO değişimi olarak verilmiştir. DNA kaynağının bitkisel standart olmaması, ilave muhafaza kimyasallarınin (gliserol, tampon çözelti) kullanılması ve kullanılan analiz metodunun farklı ( $\Delta \mathrm{Ct}$ metodu) olması gibi nedenlerle bizim çalışmamızdan farkliık göstermekle beraber dondur-çözdür uygulaması ile DNA'da degradasyonunun meydana gelebileceği de bildirilmiştir.

DNA'nin muhafaza yöntemlerinden dondurmanın enzimatik reaksiyonları inhibe etmesi, böylece oksidatif ve hidrolitik degradasyonu engellemesi sebebiyle muhafazada iyi bir yöntem olduğu bilinmektedir (Bus' ve Allen, 2014). Bu bağlamda çalışmamızda çıkan sonuçlar bu görüşü destekler niteliktedir.

Sonuç olarak; soya ve mısır DNA'larının her iki konsantrasyon (\%1 ve \%10) düzeyi için 20 dondur-çözdür uygulamasının istatiksel olarak herhangi bir etkisinin bulunmadığı görülmüştür ( $\mathrm{P}$ $>0.01$ ). Çalışma ile GDO miktar analizi yapan laboratuvarların bu analizlerde her seferinde taze olarak hazırladıkları CRM izolatlarını 20 kez dondur-çözdür döngüsüne kadar DNA degradasyonu olmadan kullanabileceği görülmüştür. Elde edilen bulguların sadece çalışma kapsamında kullanılan bitkiler ve çeşitleri için geçerli olduğunu, bundan sonra yapılacak çalışmaların diğer bitki spesifik türler ve bunlara ait çeşitler üzerinden doğrulanarak yapilması gerektiği önerilmektedir.

\section{TEŞEKKÜR}

$\mathrm{Bu}$ çalışmayı TAGEM/GYKMAE/A/19/A3/P7/01 proje numarasi ile maddi olarak destekleyen Tarımsal Araşturmalar ve Politikalar Genel Müdürlügüu'ne teşekkür ederiz.

\section{ÇIKAR ÇATIŞMASI BEYANI}

Yazarların, başka kişiler ve/veya kurumlar ile çıkar çatışması bulunmamaktadır.

\section{YAZAR KATKILARI}

AD ve NA araşturmayı tasarladı ve analizleri gerçekleştirdi. AD makaleyi yazdi. MMÇ makalenin son halini okudu ve onayladi.

\section{KAYNAKLAR}

Al-Warid, H. S. (2014). The Effect Of FreezingThawing On DNA Extraction From Cryptosporidium Oocysts In Fecal Samples. International Journal of Pharmacy and Biological Sciences, 4(1): 14-18.

Anonymous (2003). Regulation (EC) No $1829 / 2003$ of the European Parliament and Council of 22 September 2003 on genetically modified food and feed. Official Journal of the European Union, 18.10.2003-L 268/1.

Anonymous (2009). Event-specific Method for the Quantification of Soybean Event DP-3054231 Using Real-time PCR. European Commission Joint Research Centre Institute for Health and Consumer Protection Molecular Biology and Genomics Unit.

Anonymous (2010a). Biyogüvenlik kanunu, Kanun numarasi: 5997. Tarım ve Orman Bakanlığ1, R.G. 26.03.2020-27533.

Anonymous (2010b). Genetik Yapis1 Değiştirilmiş Organizmalar Ve Ürünlerine Dair Yönetmelik. Tarım ve Orman Bakanlığ1, R.G. 13.08.2010-27671.

Anonymous (2016). Kit for isolation of highquality DNA from food and feed samples, Eurofins GENESpin. Eurofins GENEScan Technologies GmbH, Germany. 
Anonymous (2018). GDO Analizlerinde Verifikasyon Rehberi. Gıda, Tarım ve Hayvancilık Bakanlı̆̆ Gida ve Kontrol Genel Müdürlügü, Nisan 2018, Ankara. https://www.tarimorman.gov.tr/GKGM/Belgel er/DB_Gida_Kont/Verifikasyon_Rehberi_GD O.pdf (Erişim tarihi: 10.10.2020).

Anonymous (2020a). The International Service for the Acquisition of Agri-biotech Applications (ISAAA).

https://www.isaaa.org/kc/cropbiotechupdate/d efault.asp (Erişim tarihi: 10.10.2020).

Anonymous (2020b). Reference materials for GMO analysis.

https://ec.europa.eu/jrc/en/research-

topic/reference-materials-gmo-analysis (Erişim tarihi: 10.10.2020).

Bellete, B., Flori, P., Hafid, J., Raberin, H., Tran Manh Sung, R. (2003). Influence of the quantity of nonspecific DNA and repeated freezing and thawing of samples on the quantification of DNA by the Light Cycler. J Microbiol Methods, 55: 213219.

Brunstein, J., (2015). Freeze-thaw cycles and nucleic acid stability: what's safe for your samples?. https://www.mloonline.com/home/article/13008425/freezethaw -cycles-and-nucleic-acid-stability-whats-safe-foryour-samples (Erişim tarihi: 10.10.2020).

Bus', M.M., Allen, M. (2014). Collecting and Preserving Biological Samples from Challenging Environments for DNA Analysis. Biopreservation and Biobanking, 12(1): 17-22.

Corbisier, P., Barbante, A., Berben, G., Broothaerts, W., De Loose, M., Emons, H., Georgieva, Tz, Lievens, A., Mazzara, M., Papazova, N., Perri, E., Sowa, S., Stebih, D., Terzi, V., Trapmann, S. (2017). Recommendation for the unit of measurement and the measuring system to report traceable and comparable results expressing GM content in accordance with EU legislation. European Commission Joint Research Centre Technical Reports. ISBN 978-92-7966971-2, https://doi.org/10.2760/177516

Fan, XJ, Huang, Y, Wu, PH, Yin, XK, Yu, XH, Fu, XH, Feng, LL, Wang, YL, Yi, HJ, Chen, ZT,
Yin, JX, Zhang, DL, Feng, WX, Bai, SM, Kim, T, Mills, GB, Lu, YL, Wan, XB, Wang, L. (2019). Impact of cold ischemic time and freeze-thaw cycles on RNA, DNA and protein quality in colorectal cancer tissues biobanking. Journal of Cancer, 10(20):

4978-

4988, https://doi.org/10.7150/jca.29372

Gaikwad, A.B. (2020). DNA storage methodologies: Principles and Protocols. http:// www.nbpgr.ernet.in/Portals/6/DMX/GENOM IC_RESOURCES/DNA\%20storage $\% 20$ metho ds-principles $\% 20$ and $\% 20$ protocols.pdf (Erişim tarihi: 10.10.2020).

Granados, A., Petrich, A., McGeer, A. \& Gubbay, J. B. (2017). Measuring influenza RNA quantity after prolonged storage or multiple freeze/thaw cycles. J Virol Methods, 247: 45-50.

Halfon, P., Khiri, H., Gerolami, V., Bourliere, M., Feryn, J. M., Reynier, P., Cartouzou, G. (1996). Impact of various handling and storage conditions on quantitative detection of hepatitis C virus RNA. J Hepatol, 25(3): 307-311.

Lahiri, D. K., Schnabel, B. (1993). DNA isolation by a rapid method from human blood samples: effects of $\mathrm{MgCl} 2$, EDTA, storage time, and temperature on DNA yield and quality. Biochem Genet, 31(7-8): 321-328.

Lee, S. B., Crouse, C. A., Kline, M. C. (2010). Optimizing storage and handling of DNA extracts. Forensic Science Review, 22(2): 131-144.

Mazzara, M., Munaro, B., Grazioli, E., Savini, C., Charles-Delobel, C., Van den Eede, G. (2013). Event-specific Method for the Quantification of Soybean Event DP-305423-1 Using Real-time PCR v. 1.01 - Validation Report and Validated Method. European Commission Joint Research Centre Institute for Health and Consumer Protection. ISBN 978-92-79-331022, https://doi.org/10.2788/21515

Rice, B. J., Haussler, D. (2018). Physical Linkage Preservation in DNA Storage. U.S. Patent Application No: 15/561, 447.

Ross, K. S., Haites, N. E., Kelly, K. F. (1990). Repeated freezing and thawing of peripheral 
blood and DNA in suspension: effects on DNA yield and integrity. J Med Genet, 27(9): 569-570.

Rossmanith, P., Röder, B., Frühwirth, K., Vogl, C., Wagner, M. (2011). Mechanisms of degradation of DNA standards for calibration function during storage. Appl Microbiol Biotechnol, 89(2): 407-417.

Röder, B., Frühwirth, K., Vogl, C., Wagner, M., Rossmanith, P. (2010). Impact of Long-Term Storage on Stability of Standard DNA for Nucleic Acid-Based Methods. Journal Of Clinical Microbiology, 48(11): 4260-4262.

Sanlidag, T., Akcali, S., Ozbakkaloglu, B. (2005). Serum hepatitis B DNA: stability in relation to multiple freeze-thaw procedures. J Virol Methods, 123(1): 49-52.

Savini, C., Bogni, A., Foti, N., Mazzara, M., Kreysa, J. (2012). Event-specific Method for the Quantification of Maize DAS-40278-9 by Realtime PCR - Validation Report and Validated Method. European Commission Joint Research Centre Institute for Health and Consumer Protection. ISBN 978-92-79-27307-0, https://doi.org/10.2788/64013
Schaudien, D., Baumgärtner, W., Herden, C. (2007). High preservation of DNA standards diluted in 50\% glycerol. Diagn Mol Pathol, 16(3): 153-157.

Shao, W., Khin, S., Kopp, W. C. (2012). Characterization of effect of repeated freeze and thaw cycles on stability of genomic DNA using pulsed field gel electrophoresis. Biopreservation and Biobanking, 10(1): 4-11.

Ünal, T.T. (2019). G1da Ve Yem Ürünlerinde GDO Tespiti İçin Yeterlilik Test Kiti Geliştirilmesi. Hacettepe Üniversitesi Fen Bilimleri Enstitüsü Gida Mühendisliği Anabilim Dalı Yüksek Lisans Tezi, Ankara, Türkiye, 172 s.

Widell, A., Månsson, A. S., Sundstrom, G., Hansson, B. G., Nordenfelt, E. (1991). Hepatitis $\mathrm{C}$ virus RNA in blood donor sera detected by the polymerase chain reaction: comparison with supplementary hepatitis $\mathrm{C}$ antibody assays. $J \mathrm{Med}$ Virol, 35(4): 253-258. 